\title{
Lesson Study as Teacher Training Model to Improve the Quality of Education: Case Study in Surakarta Indonesia
}

\author{
Tjipto Subadi $^{1, *}$, S. M. Budiyanto ${ }^{2}$, Sabar Narimo $^{2}$, Dahroni $^{1}$ \\ ${ }^{1}$ Geographical Education, School of Teacher and Training Education, Universitas Muhammadiyah Surakarta (UMS), Indonesia \\ ${ }^{2}$ Accounting Education, School of Teacher and Training Education, Universitas Muhammadiyah Surakarta (UMS), Indonesia
}

Received September 7, 2019; Revised November 8, 2019; Accepted November 15, 2019

Copyright $\bigcirc 2019$ by authors, all rights reserved. Authors agree that this article remains permanently open access under the terms of the Creative Commons Attribution License 4.0 International License

\begin{abstract}
The lesson study is very crucial to make the success of teaching learning process. The research aims to analyze the lesson study as the effective model of teacher training for improving the quality of education. This research used an approach of descriptive-qualitative phenomenology and the research design used the modified classroom action research-based on lesson study. The place of research is in Muhammadiyah PK Kota Barat Elementary School Surakarta, Indonesia. The research subjects were 30 students and 10 teachers at the PK Muhammadiyah Elementary School, while the informants are: the teachers, principals and supervisors. The data gathering employed questionnaires, interviews, and observation. The data analysis used the first order understanding and second order understanding with an interactive model, including data reduction, data display and conclusion/verification. The research results are: 1) Model of effective teacher training for improving the quality of education involves the cooperative and collaborative approaches through three main activities are: a) Workshop, b) Training, and c) Model teacher mentoring. 2) The effective model for improving the quality of teacher learning is "Modified Lesson Study Model". 3) This research also finds training that can be applied from the real state, from the simple to the more complex, and the implementation of the quality improvement strategies use cooperative and collaborative demanding the role of teachers to have better understanding.
\end{abstract}

Keywords Lesson Study, Learning, Mentoring, Quality of Education, Teacher Training

\section{The Background of Study}

The learning quality of Primary School, Junior High
School, Senior High School, Vocational School, and Higher Education can be influenced by three factors, which are: a. students (raw input) and all of their backgrounds, b. learning facilities (instrument input), c. learning environment (environmental input). Each of these inputs comprises some components. For example, the raw input includes all of the students' characteristics such as: intention, talent, intelligence, and maturity. The instrument input consists of teacher, objective, curriculum, learning textbook, method and approach, media, evaluation instrument, and facility. The environmental input covers physical environments such as: building design, location, temperature, and non-physical environments such as: family and community (Subadi, 2009). [1]

For improving the learning quality and teachers' competency, it is highly essential to consider such factors as: teachers, students, facility, laboratory, environment and management. These can be reached up through internal, external and cooperative approaches. The internal approach may refer to the professional teachers as the trainer. The external approach may refer to the teachers for taking part in workshop, training, and study. The cooperative approach may refer to the cooperation between school and higher education. Those are intended to reach the result in a qualified teacher who has an internal competency for developing his or her career and receiving a mandate as a professional teacher. Likewise, he or she must think logically, creatively, and reflectively in terms of improving a learning quality and realizing his/her thoughts and opinions in the classroom.

As one of the educational institutions, the Primary School plays a fundamental role in developing qualified Human Resources. It means that the school is the basis for subsequent education level. The recent problem is that how to improve the learning quality for achieving a qualified education. To improve the quality of learning education 
can't be separated from the role of the teacher and his/her pedagogical competence. Khofiatun, Sa'dun Akbar, M. Ramli (2016) [2] in his research concluded that the teacher's role in managing learning to improve the quality of learning requires high creativity. For example in the use of models, media, and resources related to learning in their classroom. Teachers who have good pedagogical competence tend to be succeeding in learning in their classroom. Whereas, teachers who have low pedagogical competence, do not tend to be successful in their learning.

Lesson study is one of the activity programs for improving the teacher's competency and learning quality that can be developed in the school. It can be used as the analysis study of learning practice in the form of a research based on learning for finding a given learning innovation. Essentially, this lesson study is one of the stages of developing the professional teacher in which colleague teachers serve an observer, so that it enables among teachers to share experiences.

Based on the description above, so the problem statement of the study is: how to analyze a lesson study as the effective model of teacher training for improving the quality of education. The research aim is to analyze a lesson study as the model of effective teacher training for improving the quality of education.

The Act of No. 14/2005, on Teachers and Lecturers stated that competency is a set of knowledge, skill and behavior which must be understood and mastered by teachers and lecturers in terms of serving their career as a qualified educator. [3] For enforcing the regulation this is issued by the National Education Minister's decree of Indonesian Republic of No. 17/2007 on Academic Qualification and Teacher Competency Standard. It stated that the Teacher Competency Standard is developed through four competencies: 1. Pedagogical. 2. Personality. 3. Social and. 4. Professional

According to Suell and Piotrowski (2006) [4] explained in Florida (one of the US states) possesses twelve teacher competencies, called Educator Accomplished Practices, which consist of: assessment, communication, continuous advance, critical thought, variety, ethic, human resources and learning development, substantial knowledge, environment learning, planning, teacher role, and technology.

Teachers are the professionals, the indicators to assess the professionalism if the classroom becomes "a heaven for students" or students always look forward to their teacher's attendance in the classroom" (Subadi, 2016). [5] Similarly, the teacher must play the role in a learning source as; facilitator, manager, demonstrator, consultant, motivator and evaluator. If it runs well, the approach of optimally active, creative, effective and happy learning (PAKEM) may be achieved. Note that the capacity to use this approach needs the innovative learning model.

The substance of teaching is helping the students to get information, idea, skill, value, insight of thinking, competency of expressing themselves and the way of learning (how to study). A lot of learning models developed by the experts for improving teachers' quality, include: Contextual, Quantum, Integrated, Problem-Based and Cooperative, while in most references, a cooperative learning model covers Student Team Achievement Division (STAD), Cooperative Integrated Reading and Composition (CIRC), Jigsaw, Learning Together, Group Investigation and Cooperative Scripting. A learning technique identical to the model is a structural method, developed by Spencer Kagan. This emphasizes specific structures designed to affect students' interactive model based on lesson study.

Referring to one of the practices, to enhance teacher skills and research performance is a cooperative instructor-based approach to professional development originating in Japan (Fernandez and Yoshida 2004) [6]. This Lesson study attracted the attention of the international audience in the past decade, and in 2002 it was one of the foci for the Ninth Conference of the International Congress on Mathematics Education (ICME). It subsequently spread out to many other countries and more than a dozen international conferences and workshops are held around the world in which people shared their experiences and progress with lesson study as they adopted this new form of profession.

The lesson study is training that uses a cycle system including three stages: 1) Planning, 2) Learning implementation (action) and observation, 3) Reflection (discussion). Lesson study is the most popular professional development approach whereby teachers collaborate to study content, instruction, and how the students solve their problems and reach for understanding in order to improve elementary mathematics instruction and learning in the classroom.

The lesson study is also interpreted as the analysis of teacher training process. The sequences of the process are: (1) Making an early dialogue and academic or exploration analysis of syllabus discussion, competency standard, basic competency, learning indicator and objective, development of learning materials, innovative learning method and technique, development of assessment instrument; (2) Making an academic analysis based on lesson plan (RPP); (3) Taking RPP ( Lesson Study Planning) based on learning action and inviting fellows as the observer and experts as the supervisor; (4) Making a reflection on the learning action through opinion sharing, review or commentary, and discussion with observers and supervisors; (5) Planning a continuous learning so that it forms a cycle; and (6) Implementing a lesson study program in the classroom where it must be monitored and evaluated in order to see its effectiveness, efficiency, and outcome.

As the learning-developing model, the roadmap of the research with the lesson study includes a variety of steps. According to Lewis (2002) [7], the steps of implementing a 
lesson study are: 1) Establishing a lesson study group, 2) Focusing on a lesson study, 3) Making a lesson study, 4) Implementing learning in the classroom and observing it, 5) Reflecting and analyzing a learning reflection, and 6) Planning a subsequent learning. According to Richardson (2006) [8], the steps of the lesson study for improving the teachers' quality are as follows: 1) Establishing a lesson study team, 2) Focusing on the lesson study, 3) Planning a learning, 4) Preparing observation, 5) Implementing learning and its observation, 6) Discussing a learning reflection, and 7) Planning a subsequent learning.

Sagor (1992) [9] stated that the research, the lesson study includes three steps that are: planning, implementing, and reflecting. In terms of Sagor's classroom action research, the steps of the lesson study are as follows: 1) Initiating an action, for example, adopting an idea and implementing a new strategy, 2) Monitoring and adjusting an action, and 3) Evaluating an action to prepare the report of the program completely. In an inquiry, Sagor suggested that initiating an action be usually the activity of sharing information that will help to solve the problem, called action research. In the process, it is necessary to monitor and evaluate an action related to things in the research. In the last action, it needs to evaluate an action that focuses on performance.

In conducting the present action research, structured routines are implemented in school community. The routines are basically five continuous phases of inquiry comprising 1) The problem Identification, 2) The organization of data, 3) The Data interpretation, 4) The Action based on data, and 5) The Reflection. The implemented five phases of the action research has been illustrated in Figure 1.

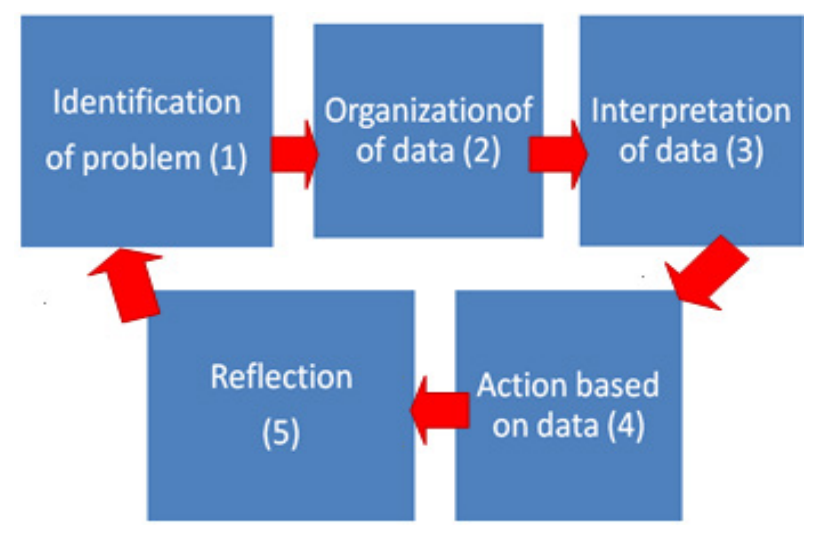

Figure 1. Action Research Cycle

\section{Method}

The research used a descriptive-qualitative phenomenology approach with social definition paradigm. The social definition paradigm causes the individuals as the subject of the research to interpret the lesson study as the model of effective teacher training for improving the quality of education. The research is carried out in Muhammadiyah PK Kota Barat Elementary School Surakarta, Indonesia. The research subjects were 30 students and 10 teachers at the PK Muhammadiyah Elementary School, and the informants consist of; the teachers, principals, and education office chief.

The research design is the classroom action research, modified in the forms of early dialogue, planning, acting and observing, and reflecting. The modified classroom action research refers to the model by Subadi (2009) [10]. The data gathering methods used are: documentation, observation interview, and test. The documentation technique is used for finding the data of the schools' and teachers' names as well as the education documents. The observation and interview are useful for the data in relation to interpret the lesson study as the model of effective teacher training for improving the quality of education. The researchers interviewed the informants by asking the interpretation of lesson study as the model of effective teacher training for improving the quality of education by using the first order understanding and second order understanding theories. The test technique is used for finding the data of the students' grade after the implementation of the lesson study for seeing the effectiveness.

The technique of the data analysis employed the interactive process. The data had been analyzed from learning activities, development of learning process to qualified learning finding. The technique refers to Miles (1992) [11] that is; the data analysis employed an interactive model, including the data reduction and presentation data, and conclusion.

\section{The Research Results and Discussion}

1. Analyzing a lesson study as a model of effective teacher training for improving the quality of education

Analyzing the lesson study is as the model of effective teacher training for improving the quality of education in primary school, which involves a cooperative and collaborative approach through three main activities mainly; a) workshop, b) training, and c) model teacher mentoring.

a. The workshop was done with the guidance and direction from an expert team. Thirty teachers (30 teachers) from primary schools in Surakarta Indonesia, attend a workshop, with the subject matter; (1) Curriculum development, (2) Policy and dynamics of curriculum development, (3) Character building priority, (4) Literacy implementation, (5) Lesson study as a model of professional teacher development, (6) Active learning, (7) Learning strategy and lesson plans development, (8) Scientific publication writing, (9) Appraisal instruments, (10) Competencies taught 
by teachers, (11) Quality learning development, (12) Peer teaching, (13) Model teacher mentoring.

b. The training was done with the guidance and direction from the expert team, in the training teachers collaborated and discussed to devise micro teaching-based lesson plan, micro teaching laboratory-based learning practices and did its reflection of previous activities.

c. The Model of teacher mentoring, this stage is divided into several activities, that is; 1) The teachers formed a lesson study team, 2) The lesson study team devised the lesson plan, 3) The lesson study team has been trained in three sessions while others became observers, and 4) The discussion after the mentoring of the model teacher. Model teacher mentoring, was implemented on model teachers of each lesson study group by using scientific approach with four cycles' system, namely; 1) Academic discussion, 2) Learning planning, 3) Learning and observation, and 4) Reflection. The four teacher model mentoring cycles' implementation are illustrated in Figure 2

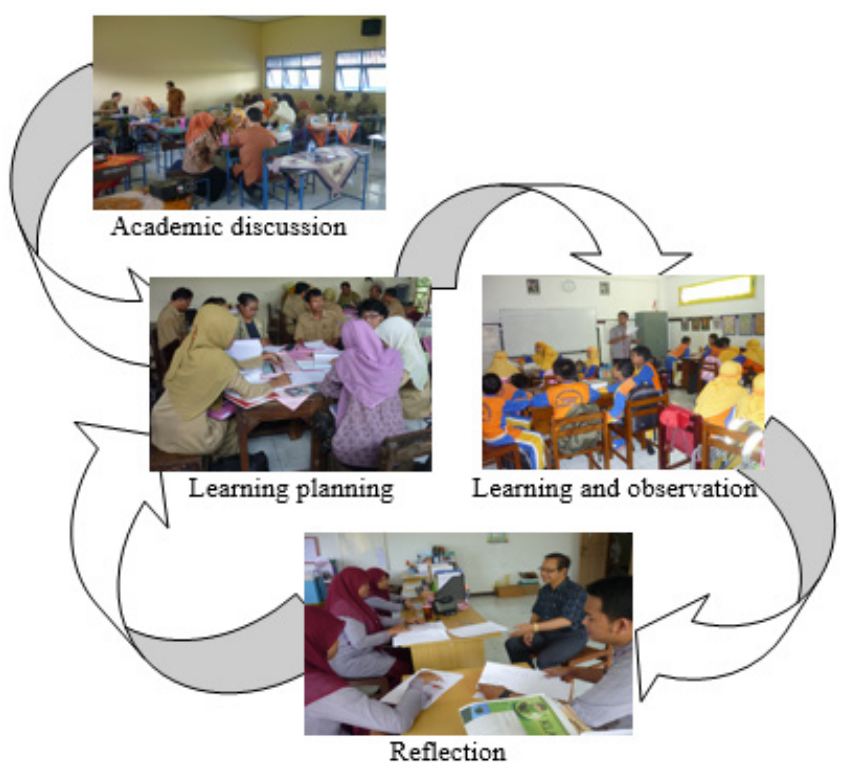

Figure 2. The Four Teacher Model Mentoring Cycles'

1) Academic discussion, teachers collaborated to examine the syllabus, core competencies/KI, basic competencies $/ \mathrm{KD}$, indicators, strategies, media, the learning activities, material development, and appraisal instruments.

2) Learning planning, the teachers collectively devised lesson plan (RPP).
3) Learning and observation, teachers implemented lesson study approach in the implementation of on 2013 Curriculum assisted by expert team. The steps are: a) Introduction (motivation, apperception, and objectives description), b) Core activity, which is the implementation of "scientific" approach (observing, questioning, reasoning, trying, networking), c) Closing (formulating a conclusion, evaluation, assignments, and follow-up).

4) Reflection, teachers discussed the implementation of lesson study carried out by model teacher. Furthermore, the results of this discussion are used to improve the preparation and subsequent implementation. The Teacher Mentoring Models can be seen in these photos.

The findings of this study are in accordance with the lesson study developed in Japan (Saito, 2006) [12]. Saito explained that lesson study involves three main activities, which are: 1) Planning, 2) Action and observation, and 3) Reflection. Similarly, Kemmis, S., \& Mc Taggart, R. (1992) [13] reasserted that lesson study is the teacher development model implemented through the cycle-by-cycle system. The first cycle is commenced with: (a) Initial reflection to define specific thematic concern, (b) Planning, (c) Action and observation, and (d) Reflection. The second cycle includes: (1) Planning revision based on the first cycle reflection, (2) Implementation of subsequent action and observation, and (3) Reflection. It is associated with the mentoring model with modified lesson study approach.

\section{The Effective Model for improving the quality}

To find out the effectiveness of the model, researchers conducted interviews with several informants; how the effectiveness of lesson study as a model of teacher development to improve the quality of learning. The results of interviews with informant 1 are as follows; Lesson study has been developed in Japan, so if it is used as a model for teacher development in Indonesia, lesson study needs to be modified. Results of interviews with informants 2; Lesson study-based teacher development will be effective, if it is adjusted to the conditions of teachers in Indonesia, therefore it is necessary to modify lesson study. Results of interviews with informants 3 ; Lesson study as a model of teacher development in Japan has been successful, but lesson study as a model of teacher development in Indonesia has also been successful, because it needs to be adjusted to the problem, for that it needs modification. A simple sample of the interview results to find out the effectiveness of lesson study can be illustrated in Figure 3 
Question

How the effectiveness of lesson study as a model of teacher development to improve the quality of learning?

\section{Informants and Answers}

\section{Informants 1}

Lesson study has been developed in Japan, so if it is used as a model for teacher development in Indonesia, leson study needs to be modified.

\section{Informants 2}

Lesson study-based teacher development will be effective, if it is adjusted to the conditions of teachers in Indonesia, therefore it is necessary to modify lesson study.

\section{Informants 3}

Lesson study as a model of teacher development in Japan has been successful, but lesson study as a model of teacher development in Indonesia has also been successful, because it needs to be adjusted to the problem, for that it needs modification.

Figure 3. The Interview Results to Find out the Effectiveness of Lesson Study

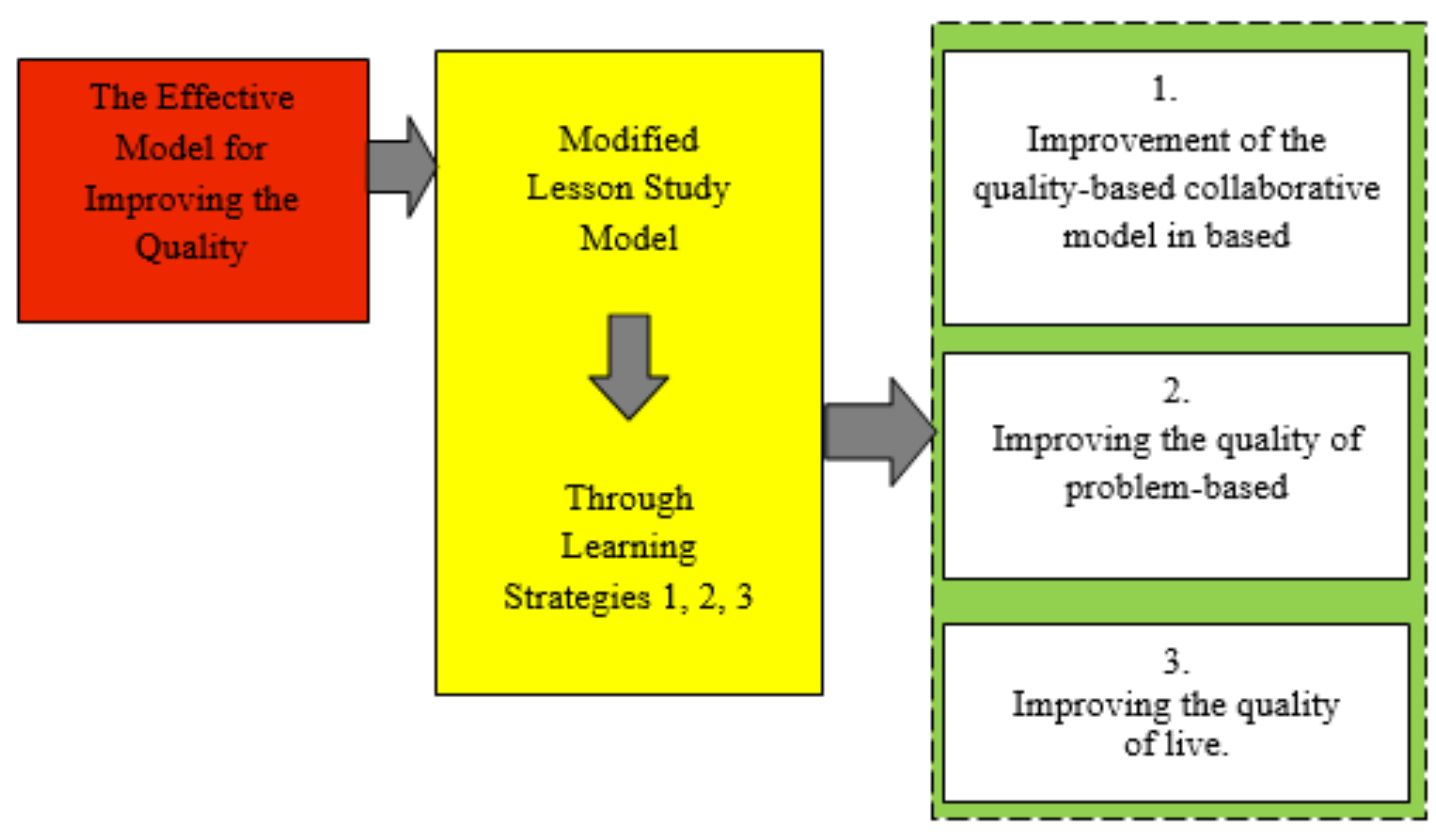

Figure 4. The Effective Model for Improving the Quality

The effective model for improving the quality of teachers' study is "Modified Lesson Study Model" through learning strategies; 1) Improvement of the quality-based collaborative model based on the achievement of the academic aspects of high among students, also learning dimension of social. 2) Improving the quality of problem-based, this model can improve the quality of learning which is based on the development of thinking skills among students through practice solving problems, and 3) Improving the quality of living. The effective model for improving the quality implemented is illustrated in Figure 4.

The findings of this study are consistent with the study of Stewart (2005) [14] entitled; "Analyzing Classroom Practice Fusion Lesson Study And Authentic Achievement: A Model For Teacher Collaboration" concluded that combination of lessons and achievements synthesized a lot of work that had been done before, but this time the 
researcher included all ideas and directions into a manageable package. The teachers will get together and work collaboratively on things that attract attention in the best way to encourage positive improvement at every grade level in a school by adopting a model modification.

3. This research also finds that the training which can be applied from the real state, from the simple to the more complex, implementation of quality improvement strategies cooperative and collaborative demanding role of teachers in several phases of learning, including; a) The formulation of objectives, perception and motivation b) Description and presentation of information through IT, c) Organizing study groups, d) The involvement of teachers in the counseling groups for the students works and learning, e) Assessing fairness, and f) Giving awards to the students who excel. The roles of the teacher in cooperative and collaborative strategies, among others are; (1) Contract of learning by communicating the Core Competencies (KI), Basic Competency (KD), indicators, learning objectives, Teaching material, reference, learning systems, and evaluation. (2) Providing information through the media, for example; boxes of information, IT, internet, if necessary, by e-mail, web and blog. (3) Forming a study group, and describing the tasks of the group. (4) Providing guidance when student group work, and accommodating student difficulties to be solved together. (5) Providing an evaluation of what has been produced by the group (6) Rewarding.

\section{Conclusions}

The conclusions of the research are:

1. The Model of the effective teacher training for improving the quality of education involves a cooperative and collaborative approach through three main activities, which are; a) Workshop, b) Training, and c) Model teacher mentoring, while the implementation of learning training using scientific approach with four cycles' system is, namely; 1) Academic discussion, 2) Learning planning, 3) Learning and observing and 4) Reflecting.

2. The effective model for improving the quality of teacher learning is "Modified Lesson Study Model"

3. "Modified Lesson Study Model" is through; a) Cooperative and collaborative learning strategies based on achieving high academic aspects, and social dimensions. b) Problem based on the learning models and c) Improving their quality of life.

4. This research also finds that the training that can be applied from the real state, from the simple to the more complex, the implementation of the quality improvement strategies cooperative and collaborative demanding role of teachers to have better understanding, while the roles of the teachers are; (1) Contract of learning (2) Providing information through the media, (3) Forminga study group, and describes the tasks of the group. (4) Providing guidance when student group work, (5) Providing the evaluation, and (6) Rewarding.

\section{REFERENCES}

[1] Subadi T. 2009. Pengembngan Model untuk Meningkatkan Kualitas Guru Melalui Pelatihan Lesson Study di Sekolah Dasar Surakarta. The Primary School Journal: a Theoritical Analyisis and Educational Practice. Year 18. No 2. November 2009. pp. 1-7

[2] Khofiatun, Sa'dun Akbar, M. Ramli. 2016. Peran Kompetensi Pedagogik Guru Dalam Pembelajaran Tematik Di Sekolah Dasar. Jurnal Pendidikan, Vol.1, No. 5, Mei 2016. pp. 984-988

[3] Departemen Pendidikan Nasional, 2005. Undang-Undang Republik Indonesia Nomor 14 Tahun 2005 Tentang Guru Dan Dosen. Depdiknas RI. Jakarta.

[4] Suell, Piotrowski. 2006. Efficacy of Alternative Teacher Certification Program: A Study of the Florida Model. Education .Vol.127. No 2. pp. 311-315

[5] Subadi T. 2016. A Development Model of Lesson Study-Based Social Science Teachers at Muhammadiyah Schools in Sukoharjo Regency, Central Java, Indonesia. The Social Sciences. Year 2016. Vol. 11. Issue 24. pp. 5919-5927

[6] Fernandez, C., \& Yoshida M. 2004. Lesson Study: A Japanese Approach to Improving Mathematics Teaching and Learning. Mahwah, NJ: Lawrence Erlbaum.

[7] Lewis, Catherine C. 2002. Lesson study: A Handbook of Teacher-Led Instructional Change. Philadelphia, PA: Research for Better Schools, Inc.

[8] Richardson J. 2006. Lesson Study: Teacher Learn How to Improve Instruction. National Staff Development Council. (Online): www.nsdc.org. 03/05/06.

[9] Sagor R. 1992. How to Conduct Collaborative Action Research, Association for Supervision and Curriculum Development, Alexandria.

[10] Subadi T., 2016. A Development Model of Lesson Study-Based Social Science Teachers at Muhammadiyah Schools in Sukoharjo Regency, Central Java, Indonesia. Journal International. The Social Sciences Year: 2016. Volume 11. Issue 24. pp. 5919-5927.

[11] Miles, B.M., \& Michael, H. 1992. Qualitative Data Analisys. Jakarta: UI Press.

[12] Saito. 2006. Development of school based in-service teacher training under an Indonesian Mathematics and Science Teacher Education Project. Improving Schools (C) SAGE Publications Volume 9 Number 1 March 2006. pp. 47-59 
[13] Kemmis, S., \& Mc Taggart, R.1992. The Action Research Planner (3rd Ed.). Geelong: Deakin University Press.

[14] Stewart R, Jonathan L. Brendefur. 2005. Fusing Lesson Study and Authentic Achievement: A Model for Teacher Collaboration. Research Article First Published May 1, 2005 Volume: 86 issue: 9, pp. 681-687 